\title{
Penerapan Asuhan Keperawatan Jiwa Pada Ny. W Dengan Masalah Isolasi Sosial
}

\author{
Hikmah Sikutiro \\ aimahsktr@gmail.com
}

\section{BAB 1}

\section{PENDAHULUAN}

\subsection{Latar Belakang}

Gangguan jiwa (psikosis) merupakan suatu keadaan jiwa yang tidak mempunyai hubungan dengan realitas, dimana selama periode gangguan jiwa, individu tersebut tidak menyadari apa yang dialami orang lain tentang hal yang sama dan orang lain tidak mempunyai respons dengan cara yang sama (Fadly \& Hargiana, 2020). Gangguan jiwa berat termasuk skizofrenia. Skizofrenia merupakan penyakit kronis, parah, dan melumpuhkan, gangguan otak yang di tandai dengan pikiran kacau, waham, delusi, halusinasi, dan perilaku aneh atau katatonik (Pardede, \& Laia. 2020).

Skizofrenia merupakan suatu gangguan jiwa berat yang bersifat berat dan kronis yang menyerang 20 juta orang di seluruh dunia (WHO, 2019). Prevalensi masalah kesehatan jiwa di Indonesia di Indonesia, estimasi jumlah penderita skizofrenia mencapai sekitar 400.000 orang atau sebanyak 1,7 per 1.000 penduduk \{Riskesdas 2013\}, sedangkan Riskesdas $\{2018\}$ juga menyebutkan sebanyak $84,9 \%$ pengidap skizofrenia/psikosis di Indonesia. Skizofrenia ditandai dengan munculnya gejala, gejala ini terdiri dari gejala positif dan gejala negatif. Gejala positif (nyata) yaitu halusinasi, waham, risiko perilaku kekerasan, isolasi sosial. Isolasi sosial atau menarik diri adalah keadaan dimana seseorang mengalami atau tidak mampu berinteraksi dengan orang lain disekitarnya. Klien mungkin merasa ditolak, tidak diterima, kesepian dan tidak mampu membina hubungan yang berarti dengan orang lain (Pardede, Hamid, \& Putri, 2020). 
Dampak dari penderita Isolasi sosial yaitu dia akan menarik diri, sulit berinteraksi dengan orang lain, kurangnya kemampuan dalam melakukan sosial, apatis terhadap lingkungan dan masyarakat, suka curiga kepada orang lain, dan juga merasa tidak tertarik dengan segala aktivitas yang sifatnya menghibur (Wahyuni, 2017). Survei awal dilakukan di Yayasan Pemenang Jiwa Sumatera dengan jumlah pasien 70 orang tetapi yang menjadi subjek di dalam pembuatan askep ini berjumlah 1 orang dengan pasien masalah Isolasi Sosial atas nama inisial Ny. W, penyebabnya Ny. W sebagai subjek di karenakan pasien belum bisa beriteraksi dengangan orang lain dan lebih sering menyendiri.

Tindakan awal yang dilakukan dalam melakukan komunikasi terapeutik pada klien isolasi sosial adalah membina hubungan saling percaya, setelah itu dilakukan tindakan keperawatan sesuai dengan strategi pelaksanaan 1-4 : menjelasakan keuntungan dan kerugian memiliki teman, melatih klien berkenalan dengan 2 orang atau lebih, melatih bercakap-cakap sambil melakukan kegiatan harian, melatih berbicara sosial meminta sesuatu dan berbelanja. Apabila mampu mengikuti tindakan keperawatan dan kooperatif sehingga diharapkan mampu terjadi peningkatan interaksi sosial pasien (Try, 2017). Berdasarkan latar belakang diatas, penulis tertarik untuk melakukan tindakan keperawatan pada klien dengan Isolasi Sosial.

\subsection{Rumusan Masalah}

Berdasarkan latar belakang masalah tersebut maka dapat dirumuskan masalah saebagai berikut : Bagaimana Memberikan Asuhan Keperawatan Jiwa Pada Ny. W dengan Isolasi Sosial di Yayasan pemenang jiwa Sumatera.

\subsection{Tujuan}

Adapun tujuanya sebagai berikut :

\subsubsection{Tujuan Umum}

Penulis mampu memberikan asuhan keperawatan jiwa pada Ny. W dengan Isolasi Sosial di Yayasan pemenang jiwa Sumatera. 


\subsubsection{Tujuan Khusus}

1. Mahasiswa mampu mengetahui defenisi, tanda \& gejala,faktor penyebab, mekanisme koping, penatalaksanaan pada pasien dengan Isolasi Sosial

2. Mahasiswa mampu melakukan pengkajian pada pasien dengan Isolasi Sosial .

3. Mahasiswa mampu menegakkan diagnosa atau masalah keperawatan pada Ny. W dengan Isolasi Sosial.

4. Mampu menetapkan intervensi keperawatan secara menyeluruh pada Ny. W dengan Isolasi Sosial.

5. Mahasiswa mampu melakukan tindakan keperawatan yang nyata pada Ny.W dengan Isolasi Sosial.

6. Mahasiswa mampu mengevaluasi sebagai tolak ukur guna menerapkan asuhan keperawatan pada $\mathrm{Ny}$. W dengan Isolasi Sosial.

7. Mahasiswa mampu mendokumentasikan asuhan keperawatan pada Ny. W dengan Isolasi Sosial.

\subsection{Manfaat}

1. Responden

Dapat meningkatkan pengetahuan tentang Isolasi Sosial sehingga dapat diterapkan dan mengatur pola hidupnya.

2. Institusi Pendidikan

Bagi institusi pendidikan diharapkan untuk menjadi acuan dalam melakukan kegiatan kemahasiswaan dalam bidang keperawatan jiwa.

3. Yayasan Pemenang Jiwa Sumatera

Diharapkan dapat menjadi acuan dalam menangani atau dalam memberikan pelayanan kepada pasien dengan gangguan jiwa degan Isolasi Sosial di Yayasan Pemenang Jiwa Sumatera. 


\section{BAB 2}

\section{TINJAUAN TEORITIS}

\subsection{Konsep Isolasi Sosial}

\subsubsection{Pengertian}

Isolasi sosial adalah di mana keadaan individu mengalami penurunan dalam berinteraksi atau bahkan tidak mampu mengalami interaksi terhadap orang di sekitarnya.Pasien dengan isolasi sosial menggalami gangguan dalam berinteraksi dan biasanya mengalami perilaku tidak ingin berkomunikasi dengan orang di sekitarnya.orang dengan isolasi sosial lebih suka berdiam diri, mengurung diri dan menghindar dari orang lain (Ni'mah \& Lailatun, 2019 ).

solasi sosial merupakan keadaan kesepian yang dialami oleh seseorang karena orang lain dianggap menyatakan sikap negatif dan mengancam bagi dirinya. Isolasi sosial adalah keadaan dimana seorang individu mengalami penurunan fungsi pikiran dan perilaku atau bahkan sama sekali tidak mampu berinteraksi dengan orang lain disekitarnya isolasi sosial sebagai suatu pengalaman menyendiri dari seseorang dan perasaan segan terhadap orang lain sebagai sesuatu yang negatif atau keadaan yang mengancam. (Pardede, Hamid \& Putri, 2020).

Isolasi sosial merupakan keadaan dimana seorang individu mengalami penurunan atau bahkan sama sekali tidak mampu berinteraksi dengan orang lain di sekitarnya. Klien mungkin merasa ditolak, tidak diterima, kesepian, dan tidak mampu membina hubungan yang berarti dengan orang lain (Pardede, 2018). 


\subsubsection{Rentang Respon}

Respon Adaptif

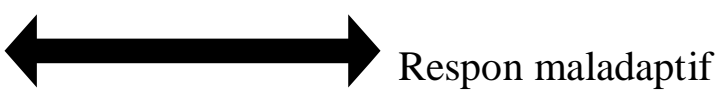

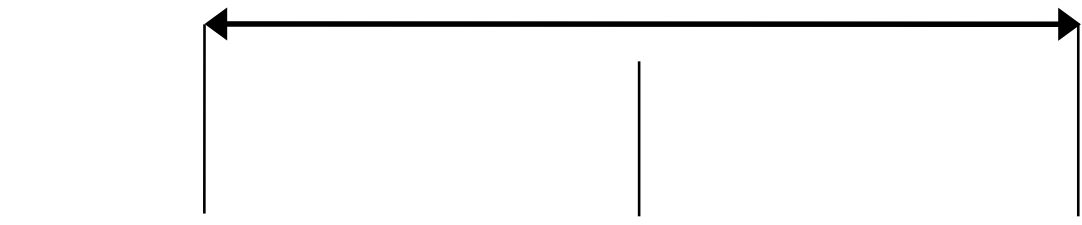

Menyendiri

Kesepian

Manipulasi

Otonomi

Menarik diri

Impulsif

Kebersaman

Ketergantungan

Narsisisme

Saling

ketergantungan

Respon adaptif adalah respon individu dalam menyelesaikan dengan cara yang dapat diterima oleh norma-norma masyarakat. Menurut Riyardi \& Purwanto. (2013) respon ini meliputi:

1. Menyendiri merupakan respon yang dilakukan individu untuk merenungkan apa yang telah terjadi atau dilakukan dan suatu cara mengevaluasi diri dalam menentukan rencana-rencana.

2. Otonomi merupakan kemampuan individu dalam menentukan dan menyampaikan ide, pikiran, perasaan dalam hubungan sosial, individu mampu menetapkan untuk interdependen dan pengaturan diri.

3. Kebersamaan merupakan kemampuan individu untuk saling pengertian, saling memberi, dan menerima dalam hubungan interpersonal.

4. Saling ketergantungan merupakan suatu hubungan saling ketergantungan saling tergantung antar individu dengan orang lain dalam membina hubungan interpersonal. Respon maladaptif adalah 
respon individu dalam menyelesaikan masalah dengan cara yang bertentangan dengan norma agama dan masyarakat.

Menurut Riyardi \& Purwanto (2013) respon maladaptif adalah:

\section{Manipulasi}

Merupakan gangguan sosial dimana individu memperlakukan orang lain sebagai objek, hubungan terpusat pada masalah mengendalikan orang lain dan individu cenderung berorientasi pada diri sendiri. Tingkah laku mengontrol digunakan sebagai pertahanan terhadap kegagalan atau frustasi dan dapat menjadi alat untuk berkuasa pada orang lain.

\section{Impulsif}

Merupakan respon sosial yang ditandai dengan individu sebagai subyek yang tidak dapat diduga, tidak dapat dipercaya, tidak mampu merencanakan tidak mampu untuk belajar dari pengalaman dan miskin penilaian

3. Narsisme

Respon sosial ditandai dengan individu memiliki tingkah laku ogosentris, harga diri yang rapuh, terus menerus berusaha mendapatkan penghargaan dan mudah marah jika tidak mendapat dukungan dari orang lain

4. solasi Sosial

Adalah keadaan dimana seorang individu mengalami penurunan atau bahkan sama sekali tidak mampu berinteraksi dengan orang lain disekitarnya. Pasien mungkin merasa ditolak, tidak diterima, kesepian, dan tidak mampu membina hubungan yang berarti dengan orang lain. 


\subsubsection{Etiologi}

Pasien dengan masalah kekurangan keterampilan sosial, tidak biasa berkomunikasi dengan orang lain secara efektif, mengalami kesulitan dalam menjalin pertemanan, mampu memecahkan masalah, menemukan dan memelihara pekerjaan, yang merupakan alasan mereka mengisolasi diri masyarakat, Keterampilan sosial yang buruk terkait erat dengan kekambuhan penyakit dan pasien kembali ke rumah sakit (Pardede \& Ramadia, 2021).

Ada beberapa faktor penyebab Isolasi Sosial \{Dermawan \& Rusdi, 2013 \} sebagai berikut :

1. Faktor presipitasi

Adapun faktor pencetus terdiri dari 4 sumber utama yang dapat menentukan alam perasaan adalah :

a. Kehilangan ketertarikan yang nyata atau yang di bayangkan, termasukkehilangan cinta seseorang. Fungsi fisik, kedudukan atau harga diri, karenaelemen aktual dan simbolik melibatkan konsep kehilangan, maka konseppersepsi lain merupakan hal yang sangat penting.

b. Peristiwa besar dalam kehidupan, sering di laporkan sebagai pendahuluepisode depresi dan mempunyai dampak terhadap masalah- masalah yang dihadapi sekrang dan kemampuan menyelesaikan masalah.

c. Peran dan ketegangan peran telah di laporkan mempengaruhi depresiterutama pada wanita.

d. Perubahan fisiologis di akibatkan oleh obat-obatan berbagai penyakit fisikseperti infeksi, gangguan keseimbangan metabolik dapat mencetus gangguan alam perasaan.

2. Faktor predisposisi

a. Faktor perkembangan 
Tiap gangguan dalam pencapian tugas perkembangan dari masa bayisampai dewasa tua akan menjadi pencetus seseorang sehingga mempunyaimasalah respon sosial menarik diri. Organisasi anggota keluarga bekerjasama dengan tenaga kerja profesional untuk mengembangkan gambaranyang lebih tepat tentanghubungan antara kelainan jiwa dan stress keluarga. Pendekatan kolaboratif dapat mengurangi masalah respon sosial menarik diri.

b. Faktor biologik

Faktor genetik dapat menunjang terhadap respon sosial maladaptif.Genetik merupakan salah satu faktor pendukung gangguan jiwa.Kelainanstruktur otak, seperti atropi, pembesaran ventrikel, penurunan berat danvolume otak serta perubahan limbik di duga dapat menyebabkan skizofrenia

c. Faktor sosiokultural

Isolasi sosial merupakan faktor dalam gangguan berhubungan. Inimerupakan akibat dari norma yang tidak mendukung pendekatan terhadaporang lain, atau tidak menghargai anggota masyarakat yang tidak produktif,seperti lansia, orang cacat dan berpenyakit kronik. Isolasi dapat terjadikarena mengadopsi norma, perilaku dan sistem nilai yang di miliki budayamayoritas. Harapan yang tidak realistis terhadap hubungan merupakan faktorlain yang berkaitan dengan gangguan ini.

\subsubsection{Manifestasi Klinis}

Tanda dan gejala isolasi sosial meliputi : Kurang spontan, Apatis (acuh tak acuh terhadap lingkungan), Ekspresi wajah kurang berseri (ekspresisedih), Afek tumpul, Tidak merawat dan memperhatikan kebersihan diri, Tidak ada atau kurang terhadap komunikasi verbal, Menolak berhubungan dengan oranglain, Mengisolasi diri (menyendiri), 
Kurang sadar dengan lingkungan sekitarnya, Asupan makan dan minuman terganggu, Aktivitas menurun dan Rendah diri (Damanik, Pardede, \& Manalu, 2020).

Tanda dan gejala yang muncul pada klien dengan isolasi social : menarik diri (Dermawan dan Rusdi, 2013) seperti:

\subsubsection{Gejala Subyektif}

1. Klien menceritakan perasaan kesepian atau ditolak oleh orang lain

2. Klien merasa tidak aman berada dengan orang lain

3. Respon verbal kurang atau singkat

4. Klien mengatakan hubungan yang tidak berarti dengan orang lain

5. Klien merasa bosan dan lambat menghabiskan waktu

6. Klien tidak mampu berkonsentrasi dan membuat keputusan

7. Klien merasa tidak berguna

8. Klien tidak yakin dapat melangsungkan hidup

9. Klien merasa ditolak

\subsubsection{Gejala Objektif}

1. Klien banyak diam dan tidak mau bicara

2. Tidak mengikuti kegiatan

3. Banyak berdiam diri di kamar

4. Klien menyendiri dan tidak mau berinteraksi dengan orang yang terdekat

5. Klien tampak sedih, ekspresi datar dan dangkal

6. Kontak mata kurang

7. Kurang spontan

8. Apatis (acuh terhadap lingkungan)

9. Ekpresi wajah kurang berseri

10. Tidak merawat diri dan tidak memperhatikan kebersihan diri

11. Mengisolasi diri

12. Tidak atau kurang sadar terhadap lingkungan sekitarnya 
13. Memasukan makanan dan minuman terganggu

14. Retensi urine dan feses

15. Aktifitas menurun

16. Kurang energi (tenaga)

17. Rendah diri

18. Postur tubuh berubah, misalnya sikap fetus/janin (khusunya pada posisi tidur.

\subsubsection{Patofisiologi}

Salah satu gangguan berhubungan sosial diantaranya perilaku menarik diri atau isolasi social yang disebabkan oleh perasaan tidak berharga, yang bias dialami klien dengan latar belakang yang penuh dengan permasalahan, ketegangan, kekecewaan dan kecemasan (Dermawan dan Rusdi, 2013)

Perasaan tidak berharga menyebabkan klien makin sulit dalam mengembangan hubungan dengan orang lain. Akibatnya klien menjadi regresi atau mundur, mengalami penurunan dalam aktifitas dan kurangnya perhatian terhadap penampilan dan kebersihan diri.Klien semakin tenggelam dalam perjalanan dan tingkah laku masa lalu serta tingkah laku primitive antara lain pembicaraan yang autistic dan tingkah laku yang tidak sesuai dengan kenyataan, sehingga berakibat lanjut menjadi halusinasi (Azizah \& Wardani, 2017).

\subsubsection{Komplikasi}

Isolasi Sosial Orang menjadi menarik diri, malas beraktifitas, tidak mampu mengatasi masalah, rasa malu dan bersalah yang berlebihan dampak yang ditimbulkan dari isolasi sosial adalah menarik diri, narcissism atau mudah marah, melakukan hal yang tak terduga atau impulsivity, memberlakukan orang lain seperti objek, halusinasi dan defisit perawatan diri (Damanik, Pardede, \& Manalu, 2020). 


\subsection{Konsep Dasar Keperawatan}

\subsubsection{Pengkajian Keperawatan}

Identitas ditulis lengkap meliputi nama, usia dalam tahun, alamat, pendidikan, agama, status perkawinan, pekerjaan, jenis kelamin, nomer rekam medis dan diagnosa medisnya

1. Faktor Predisposisi

Faktor predisposisi penyebab isolasi soasial meliputi faktor perkembangan, faktor biologis, dan faktor sosiokultural (Damaiyanti dan Iskandar 2013).

a. Faktor Perkembangan

Setiap tahap tumbuh kembang memiliki tugas yang harus dilalui individu dengan sukses, karena apabila tugas perkembangan ini tidak dapat terpenuhi, akan menghambat masa perkembangan selanjutnya.

b. Faktor Biologis

Genetik merupakan salah satu faktor pendukung gangguan jiwa. Insiden tertinggi skizofrenia, misalnya, ditemukan pada keluarga dengan riwayat anggota keluarga yang menderita skizofrenia.

c. Faktor Psikologis

Tingkat kecemasan yang berat akan menyebabkan menurunnya kemampuan individu untuk berhubungan dengan orang lain. Intensitas kesemasan yang ekstrim dan memanjang disetrai terbatasnya kemampuan individu untuk mengatasi masalah diyakini akan menimbulkan berbagai masalah gangguan berhubungan (menarik diri).

d. Faktor Sosiokultural

Isolasi sosial atau mengasingkan diri dari lingkungan merupakan faktor pendukung terjadinya gangguan berhubungan. Dapat juga disebabkan oleh karena norma-norma yang salah yang dianut 
oleh satu keluarga, seperti anggota tidak produktif diasingkan dari lingkungan sosial.

\section{Faktor Presipitasi}

Menurut Damaiyanti \& iskandar (2013), Stressor prespitasi terjadinya isolasi sosial dapat ditimbulkan oleh faktor internal maupun eksternal, meliputi:

a. Stresor Sosial Budaya

Stresor sosial budaya dapat memicu kesulitan dalam berhubungan terjadinya penurunan stabilitas keluarga seperti perceraian, berpisah dengan orang yang dicintai, kehilangan pasangan pada usia tua, kesepian karena ditinggal jauh, dirawat di rumah sakit, atau dipenjara. Semua ini dapat menimbulkan isolasi sosial.

\section{Sumber Koping}

Sumber koping meliputi, kemampuan personal, dukungan sosial, aset materi dan keyakinan . kemampuan personal yang harus dimiliki yaitu, mampu berinteraksi dengan orang lain, mampu memulai pembicaraan. Dukungan sosial dapat di dapat dari sumber daya keluarga, seperti pemahaman orang tua tentang penyakit, ketersediaan keuangan, ketersediaan waktu dan tenaga, dan kemampuan untuk memberikan dukungan yang berkelanjutan, memengaruhi jalannya penyesuaian setelah gangguan jiwa terjadi (Stuart, 2016).

\subsection{Diagnosa Keperawatan}

Menurut Damaiyanti (2012) adapun diagnosa keperawatan pasien yang muncul pada pasien dengan isolasi sosial adalah sebagai berikut: Isolasi Sosial dan Harga Diri Rendah Kronik 


\subsection{Intervensi keperawatan}

Rencana tindakan keperawatan untuk pasien Isolasi Sosial (Sulastri, 2017).

1. Tujuan umum dan tujuan khusus Strategi pelaksanaan tindakan keperawatan untuk individu yaitu meliputi: pada pasien dengan isolasi sosial terdapat

a. Pasien dapat berinteraksi dengan orang lain.

b. Pasien dapat membina hubungan saling percaya.

2. Tindakan keperawatan

a. Strategi pelaksanaan tindakan keperawatan (SP 1) untuk individu yaitu pengkajian isolasi sosial, dan keuntungan dan kelebihan mempunyai teman

b. Strategi pelaksanaan tindakan keperawatan (SP 2) untuk individu yaitu melatih pasien berinteraksi secara bertahap (pasien dengan 2 orang lain), latihan bercakap-cakap saat melakukan 2 kegiatan harian

c. Strategi pelaksanaan tindakan keperawatan (SP 3) untuk individu yaitu melatih pasien berinteraksi secara bertahap (pasien dengan 45 orang), latihan bercakap-cakap saat melakukan 2 kegiatan harian baru.

d. Strategi pelaksanaan tindakan keperawatan (SP 4) untuk individu yaitu mengevaluasi kemampuan berinteraksi, melatih cara berbicara saat melakukan kegiatan sosial.

\subsection{Implementasi Keperawatan}

Proses implementasi adalah melaksanakan rencana tindakan yang sudah disusun dan disesuaikan dengan kondisi pasien saat itu. Pelaksanaan tindakan keperawatan bisa lebih dari apa yang telah direncanakan atau lebih sedikit dari apa yang sudah direncanakan bahkan mampu memodifikasi dari perencanaan yang telah disesuaikan dengan kebutuhan pasien pada saat asuhan keperawatan diberikan. 
Dalam mengimplementasikan intervensi, perawat kesehatan jiwa menggunakan intervensi yang luas yang dirancang untuk mencegah penyakit meningkat, mempertahankan, dan memulihkan kesehatan fisik dan mental (Damaiyanti, 2013).

\subsection{Evaluasi}

Pada evaluasi perawat mengevaluasi respon pasien berdasarkan kemampuan yang sudah diajarkan pada pasien, berupa evaluasi yang dapat dilakukan untuk menilai respon verbal dan non verbal yang dapat diobservasi oleh perawat berdasarkan respon yang ditunjukkan oleh pasien (Fadly, \& Hargiana, 2018).

Evaluasi dapat dilakukan dengan menggunakan pendekatan SOAP:

S : Respon subyektif pasien terhadap tindakan keperawatan yang telah dilaksanakan.

$\mathrm{O}$ : Respon obyektif pasien terhadap tindakan keperawatan yang telah dilaksanakan.

A : Analisa ulang atas data subyektif dan obyektif atau muncul untuk menyimpulkan apakah masalah baru atau ada data yang kontradiksi dengan masalah yang ada.

P : Perencanaan atau tindak lanjut berdasarkan hasil analisa pada respon pasien. Latihan kemampuan yang sudah diajarkan untuk mengontrol perilaku isolasi sosial 


\section{BAB 3}

\section{TINJAUAN KASUS}

\subsection{Identitas Klien}

$\begin{array}{ll}\text { Inisial } & : \text { Ny. S } \\ \text { Jenis kelamin } & : \text { Perempuan } \\ \text { Umur } & : \text { 52 Tahun } \\ \text { Agama } & : \text { Budha } \\ \text { Status } & : \text { Menikah } \\ \text { Tanggal pengkajian } & \text { 05 Maret } 2021 \\ \text { Informant } & : \text { Status klien dan komunikasi dengan klien. }\end{array}$

\subsection{Alasan Masuk}

Alasan klien masuk yayasan pemenangan jiwa adalah klien mengatakan klien dibawa oleh keluarga, dalam keadaan tidak bersih . keluarga klien mengatakan klien sering menyendiri, tidak mau bergaul dengan orang lain, berdiam diri di kamar tidak mau berbicara.

\subsection{Faktor Predisposisi}

Klien sebelumnya pernah belum pernah mengalami gangguan jiwa \pm 6 tahun yang lalu tepatnya pada tahun 2016 klien di ceraikan oleh suaminya dan ditinggalkan oleh anaknya yang sibuk bekerja di singapura dan malaysia, dan setelah kejadian tersebut Klien tampak menyendiri, tidak bersemangat, suara pelan hampir tidak terdengar, kontak mata kurang, selalu menunduk, tidak berani memulai pembicaraan, klien tampak tidur telentang menghadap keatas.

\subsection{Fisik}

Klien mengatakan susah berjalan karena pernah mengalmi patah tulang daerah paha , saat dilakukan pemeriksaan tanda-tanda vital, didapatkan hasil TD : 110/80 $\mathrm{mmHg} ; \mathrm{N}: 80 \mathrm{x} / \mathrm{i} ; \mathrm{S}: 36,5^{\circ} \mathrm{C} ; \mathrm{P}: 20 \mathrm{x} / \mathrm{i}$. Klien memiliki tinggi badan $155 \mathrm{~cm}$ dan berat badan $65 \mathrm{Kg}$. 


\subsection{Psikososial}

\subsubsection{Genogram}

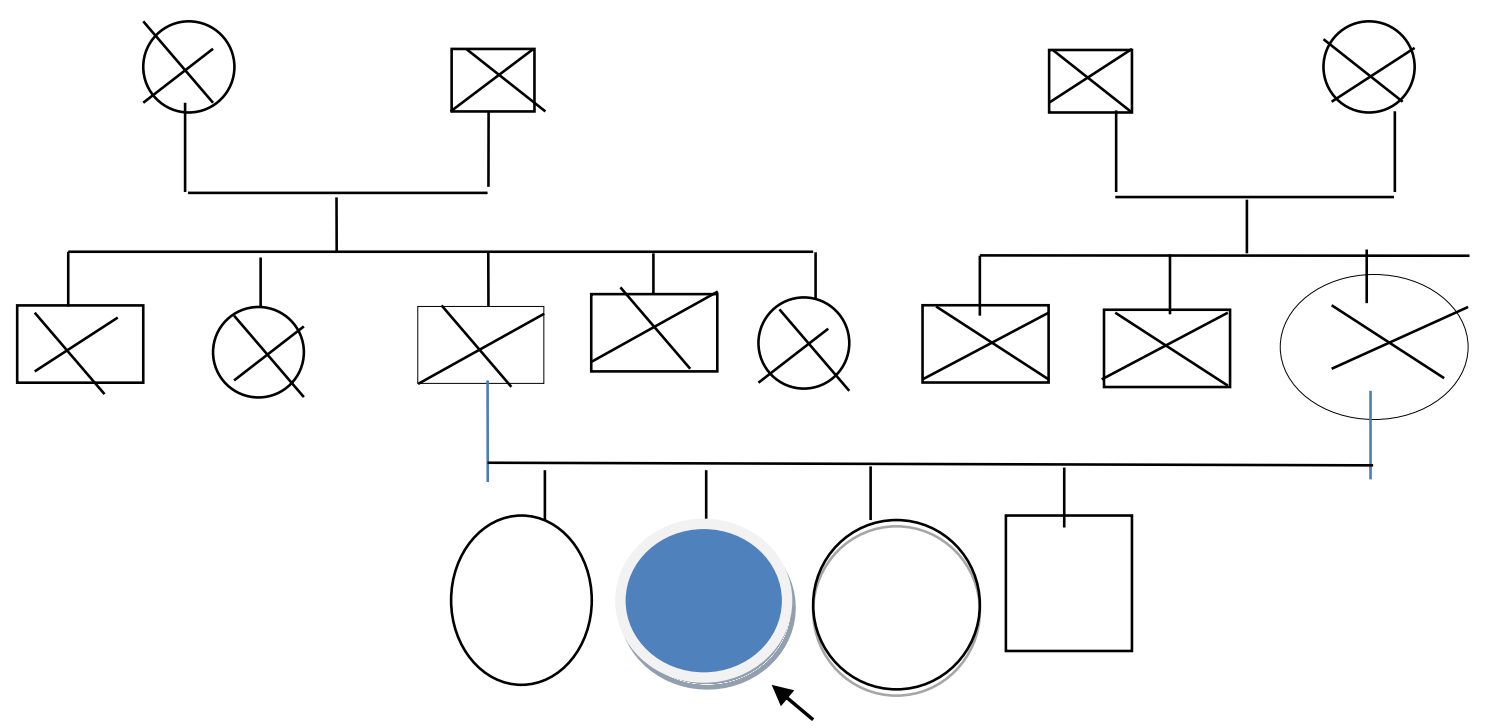

Penjelasan :

Klien anak ke 2 dari 4 bersaudara, klien brinisial Ny. W, anak yatim piatu, ayah ibunya sudah meninggal saat usia klien 36 tahun Ny.W sudah menikah

Keterangan :

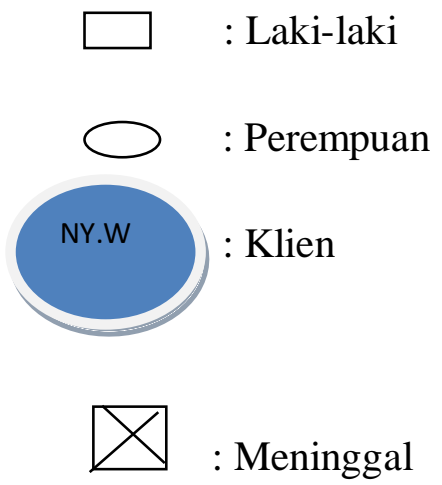

\subsubsection{Konsep Diri}

1. Gambaran diri : : klien hanya diam

2. Identitas : Klien anak ke 2 dari 4 bersaudara, klien hanya lulusan SMA yang saat ini dirawat di yayasan pepenang jiwa medan 
3. Peran : Klien berperan sebagai ibu dari 4 orang anak, klien sebelunya tinggal bersama keluarganya. Sebelum suami dan anaknya meninggalkan dia

4. Ideal diri : Klien merasa malu karena di antarkan ke yayasan pemenangan jiwa tersebut

5. Harga diri : Klien merasa apakah dirinya tidak diangga sebagai seorang ibu lagi karena, karena dirinya di tempatkan ditempat ini Masalah keperawatan: Gangguan konsep diri : harga diri rendah

\subsubsection{Hubungan sosial}

1. Orang yang berarti : kakak

2. Peran serta dalam kegiatan kelompok / masyarakat : tidak berperan dalam kegiatan sosial

3. Hambatan dalam berbuhungan dengan orang Lain : klien hanya diam dan tidak mau menjawab jika di ajak bicara

Masalah keperawatan: isolasi social

\subsubsection{Spiritual}

Nilai dan Keyakinan : Klien beragama Budha

Kegiatan Ibadah $\quad$ : Ibadah 3 kali sehari. Yaitu pagi 2 kali sekitar pukul 6 pagi dan pukul 10 pagi, selanjutnya jam 7 malam.

\subsubsection{Status Mental}

Cara berpakian rapi, penampilan dari rambut sampai kaki rapi dan bersih.

Klien tidak mampu memulai pertanyaan, dan hanya menjawab kalimat singkat ketika diberi pertanyaan, suara pelan hampir tidak terdengar. Aktivitas motorik, Klien tampak tegang ketika diajak berinteraksi. Alam perasaaan, klien mengatakan malu dan takut berinteraksi dengan orang baru. klien hanya merespon ketika diberi pertanyaan. Kontak mata kurang, klien merasa asing apabila berinteraksi dengan orang baru ataupun lingkungan yang baru, sebab dari pengalaman hidup semasa kecil klien jarang berinteraksi dengan orang baru ataupun lingkungan luar rumah. 


\subsection{Masalah psikososial dan lingkungan}

Klien memiliki masalah dalam berhubungan dengan lingkungan karena stigma masyarakat terhadap dirinya yang di rawat di yayasan pemenang jiwa

Masalah keperawatan : isolasi sosial

\subsection{Aspek Medis}

Diagnosa Medis :

1. Isolasi sosial

2. Harga diri rendah kronis

Terapi medik : pemberian/minum obat secara teratur

1. Haloperidol $2 \times 2,5 \mathrm{mg}$

2. Trihexyphenidyl $2 \times 2 \mathrm{mg}$

\subsection{Analisa Data}

\begin{tabular}{|l|l|c|}
\hline No. & \multicolumn{1}{|c|}{ Data } & Masalah \\
\hline 1. & $\begin{array}{l}\text { Data Subjektif: } \\
\text { keluarga klien mengatakan klien sering } \\
\text { menyendiri }\end{array}$ & Isolasi sosial : \\
& $\begin{array}{l}\text { Data Obyektif: } \\
\text { klientampak menyendiri, suka menggaruk- } \\
\text { garukan kepalanya ketika diajak berbicara, } \\
\text { Menghindari kontak mata menghindari } \\
\text { bertemu dengan orang baru , lebih suka } \\
\text { menyendiri didalam kamar klien selalu } \\
\text { menunduk, tidak berani memulai pembicaraan. }\end{array}$ & \\
\hline
\end{tabular}




\begin{tabular}{|l|l|l|}
\hline 2 & $\begin{array}{l}\text { Data Subjektif : } \\
\text { pasien mengatakan dia tidak mau bergaul } \\
\text { dengan orang lain karena merasa di } \\
\text { rendahkan karena ditinggal oleh suami dan } \\
\text { anaknya di tempat ini, dan seperti tidak }\end{array}$ & \\
dianggap sebagai ibu & \\
Data objektif: & \\
klien tampak terlihat malu ketika diajak \\
berbicara mengenai masa lalunya, tidak berani \\
memulai pembicaraan, dan terlihat sedih saat \\
dikaji
\end{tabular}

\subsection{Daftar Masalah Keperawatan}

1. Isolasi Sosial

2. Gangguan konsep diri : Harga Diri Rendah Kronis

\subsection{Pohon masalah}

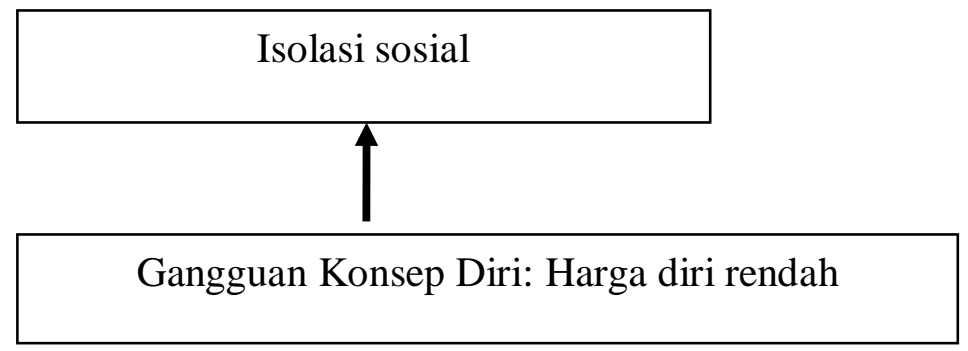

\subsection{Diagnosa prioritas}

1. Isolasi Sosial 


\subsection{Intervensi keperawatan}

\begin{tabular}{|c|c|c|c|}
\hline $\begin{array}{c}\text { Diagnosa } \\
\text { keperawatan }\end{array}$ & Tujuan & Kriteria hasil & Intervensi \\
\hline Isolasi Sosial & $\begin{array}{l}\text { Klien dapat membina } \\
\text { hubungan saling percaya }\end{array}$ & $\begin{array}{l}\text { Ekspresi wajah bersahabat, } \\
\text { menunjukkan rasa senang, ada } \\
\text { kontak mata, mau berjabat tangan, } \\
\text { mau menyebutkann nama, mau } \\
\text { menjawab salam, klien mau } \\
\text { duduk berdampingan dengan } \\
\text { perawat, mau mengutarakan } \\
\text { masalah yang di } \\
\text { hadapi. }\end{array}$ & $\begin{array}{l}\text { 1.Bina hubungan saling percaya dengan } \\
\text { mengungkapkan prinsip komunikasi } \\
\text { terapeutik: } \\
\text { a. Sapa klien dengan ramah, baik verbal } \\
\text { maupun non verbal } \\
\text { b. Perkenalkan diri dengan sopan } \\
\text { c. Tanyakan nama lengkap klien \& } \\
\text { nama panggilan yang disukai klien } \\
\text { d. Jelaskan tujuan pertemuan } \\
\text { e. Jujur dan menepati janji } \\
\text { f. Tunjukkan sikap empati dan } \\
\text { menerima klien apa adanya } \\
\text { g. Beri perhatian pada klien dan } \\
\text { perhatian kebutuhan dasar pasien } \\
\text { menarik diri Klien dapat menyebutkan penyebab }\end{array}$ \\
\hline
\end{tabular}




\begin{tabular}{|c|c|c|c|}
\hline & & & $\begin{array}{l}\text { a. Kaji perilaku klien tentang perilaku } \\
\text { menarik diri dan tanda-tandanya. } \\
\text { b. Beri kesempatan kepda klien untuk } \\
\text { mengungkapkan perasaan penyebab } \\
\text { menarik diri atau tidak mau bergaul. } \\
\text { c. Diskusikan bersama klien tentang } \\
\text { perilaku menarik diri, tanda-tanda serta } \\
\text { penyebab yang muncul. } \\
\text { d. Berikan pujian terhadap kemampuan } \\
\text { klien dalam mengungkapkan } \\
\text { perasaannya. }\end{array}$ \\
\hline & $\begin{array}{l}\text { menyebutkan keuntungan } \\
\text { berhubungan dengan } \\
\text { orang lain, dan kerugian } \\
\text { tidak berhubungan } \\
\text { dengan irang lain. }\end{array}$ & \begin{tabular}{|lr} 
klien dapat menyebutkan & kerugian \\
keuntungan dan & kengan orang lain \\
berhubungan dengan
\end{tabular} & $\begin{array}{l}\text { SP-1 } \\
\text { 1. Kaji pengetahuan klien tentang manfaat } \\
\text { dan keuntungan berhubungan dengan } \\
\text { orang lain. } \\
\text { 2. Beri kesempatan klien untuk } \\
\text { mengungkapkan perasaannya } \\
\text { tentang keuntungan berhubungan } \\
\text { dengan orang lain. } \\
\text { 3. Diskusikan bersama klien tentang }\end{array}$ \\
\hline
\end{tabular}




\begin{tabular}{|c|c|c|}
\hline & & $\begin{array}{l}\text { keuntungan berhubungan dengan } \\
\text { orang lain. } \\
\text { 4. Beri reinforcement positif terhadap } \\
\text { kemampuan pengungkapan perasaan } \\
\text { tentang keuntungan berhubungan } \\
\text { dengan orang lain. } \\
\text { 5. Kaji pengetahuan klien tentang } \\
\text { manfaat dan kerugian tidak } \\
\text { berhubungan dengan orang lain } \\
\text { 6. Beri kesempatan kepada klien untuk } \\
\text { mengungkapkan perasaan tentang } \\
\text { kerugian tidak berhubungan dengan } \\
\text { orang lain. } \\
\text { 7. Diskusikan bersama klien tentang } \\
\text { kerugian tidak berhubungan dengan } \\
\text { orang lain. } \\
\text { 8. Beri reinforcement positif terhadap } \\
\text { kemampuan n tentang kerugian tidak } \\
\text { berhubungan dengan orang lain. }\end{array}$ \\
\hline Klien dapat & Klien dapat mendemonstrasikan & SP-2 \\
\hline
\end{tabular}




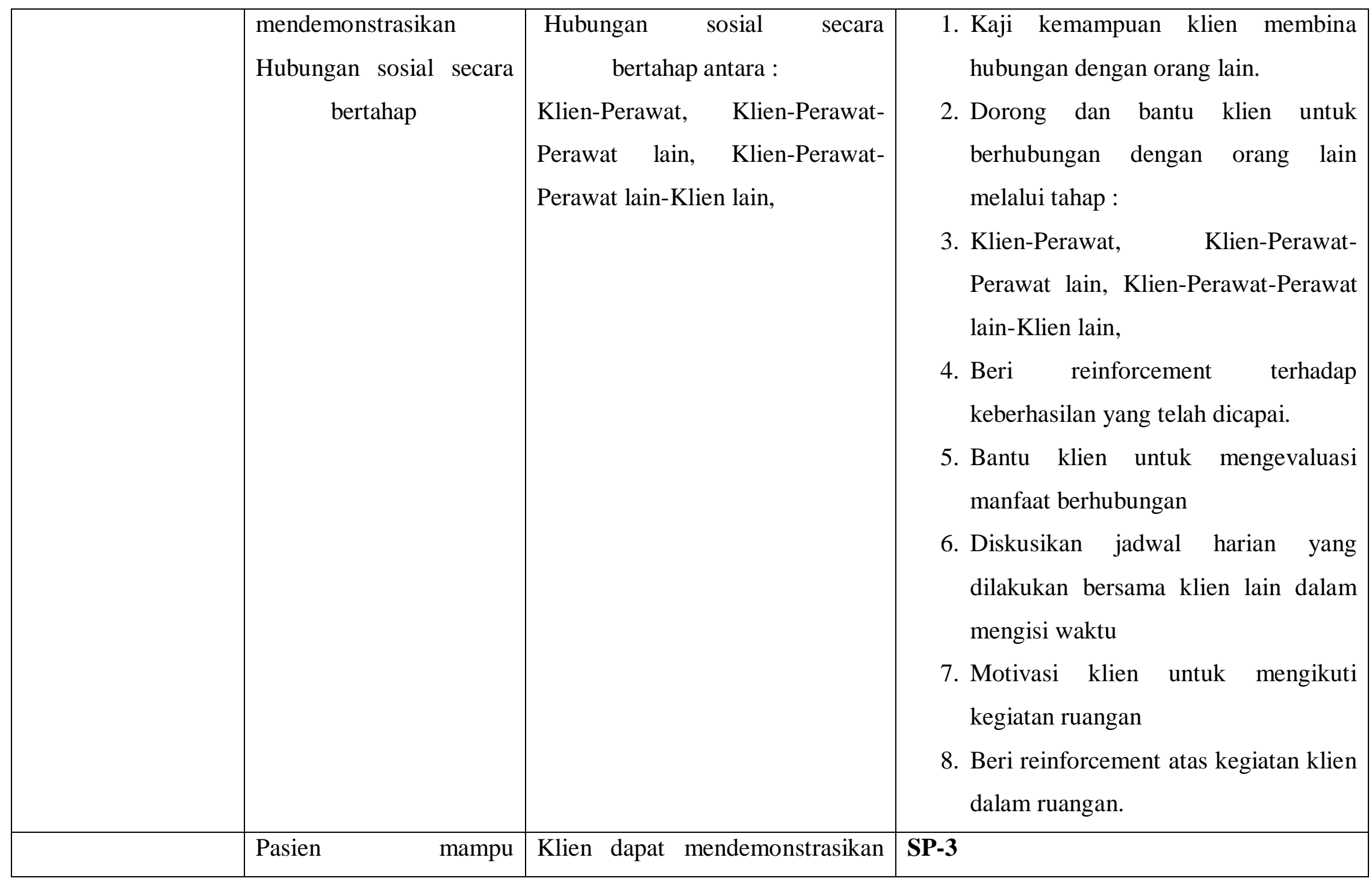




\begin{tabular}{|c|c|c|c|}
\hline & $\begin{array}{l}\text { berhubungan sosial } \\
\text { dengan cara bertahap }\end{array}$ & $\begin{array}{llr}\text { secara } & \text { bertahap } & \text { dengan } \\
\text { melakukan } & \text { berbincang } & \text { bincang } \\
\text { sambil melakukan kegiatan harian }\end{array}$ & $\begin{array}{l}\text { 1. Menjelaskan dan melatih klien } \\
\text { bercakap-cakap saat melakukan } \\
\text { kegiatan harian. }\end{array}$ \\
\hline & $\begin{array}{l}\text { Pasien mampu } \\
\text { berhubungan sosial } \\
\text { dengan cara bertahap }\end{array}$ & $\begin{array}{l}\text { Klien dapat mendemonstrasikan } \\
\text { secara bertahap dengan } \\
\text { melakukan kegiatan berbelanja } \\
\text { atau meminta sesuatu }\end{array}$ & $\begin{array}{l}\text { SP-4 } \\
\text { 1. Memberikan kesempatan pada klien } \\
\text { memperaktikan cara meminta sesuatu } \\
\text { 2. Memberikan kesempatan pada klien } \\
\text { berbelanja dan lainya }\end{array}$ \\
\hline $\begin{array}{l}\text { Harga diri rendah } \\
\text { kronis }\end{array}$ & $\begin{array}{l}\text { Klien dapat } \\
\text { mengidentifikasi } \\
\text { kemampuan dan aspek } \\
\text { positif yang ia miliki }\end{array}$ & $\begin{array}{l}\text { Kemampuan yang dimiliki } \\
\text { klien }\end{array}$ & $\begin{array}{l}\text { SP1 :mengidentifikasi aspek positif yang } \\
\text { dimilki klien } \\
\text { SP2 : } \\
\text { a. Menilai kemampuan yang dapat } \\
\text { digunakann } \\
\text { b. Menetapkan/ memilih kegiatan } \\
\text { sesuai kemampuan } \\
\text { c. Melatih kegiatan sesuai dengan } \\
\text { kemampuan yang dipilih } \\
\text { SP3 : mengidentifikasi aspek postif yang } \\
\text { dimilki klien 2 } \\
\text { SP4 : mengidentifikasi aspek positif yang }\end{array}$ \\
\hline
\end{tabular}




\begin{tabular}{|l|l|l|l|}
\hline & & dimilki klien 3 \\
\hline
\end{tabular}

\subsection{Implementasi Dan Evaluasi Keperawatan}

\begin{tabular}{|c|c|c|}
\hline Hari/ Tgl & Implementasi & Evaluasi \\
\hline $\begin{array}{l}\text { Selasa, } 09 \text { Maret } 2021 \\
\text { Jam } 10.00 \text { wib }\end{array}$ & $\begin{array}{l}\text { Membina hubungan saling percaya antara klien dan } \\
\text { perawat dengan mengungkapkan prinsip } \\
\text { komunikasi terapeutik : } \\
\text { 1. Menyapa klien dengan ramah, baik verbal } \\
\text { maupun non verbal } \\
\text { 2. Memperkenalkan diri dengan sopan } \\
\text { 3. Menanyakan nama lengkap klien \& nama } \\
\text { panggilan yang disukai klien } \\
\text { 4. Menjelaskan tujuan pertemuan } \\
\text { 5. Menunjukkan sikap empati dan menerima } \\
\text { klien apa adanya } \\
\text { Rencana Tindak Lanjut : } \\
\text { SP } 1 \text { Isolasi Sosial: }\end{array}$ & $\begin{array}{l}\text { O : - Pasien belum mampu mengenali masalah } \\
\text { isolasi social dengan mandiri } \\
\text { A : isolasi sosial (+) } \\
\text { P : lanjutkan SP } 2 . \\
\text { - latihan memperkenalkan diri nama, umur, } \\
\text { tempat tinggal, hobi } \\
\text { - } \text { Selamat pagi, saya latihan berkenalan, } \\
\text { selamat pagi perkenalkn nama saya W } \\
\text { hobi memasak kue, asal saya dari medan, } \\
\text { - latihan berkenalan dengan orang lain } \\
\text { - Selamat pagi, saya latihan berkenalan, } \\
\text { selamat pagi perkenalkn nama saya W }\end{array}$ \\
\hline
\end{tabular}




\begin{tabular}{|c|c|c|}
\hline & $\begin{array}{l}\text { 1. Mengidentifikasi penyebab Isolasi Sosial } \\
\text { 2. Berdiskusi dengan klien tentang keuntungan } \\
\text { bila berhubungan dengan orang lain. } \\
\text { 3. Berdiskusi dengan klien tentang kerugian } \\
\text { bila tidak berhubungan dengan orang lain. } \\
\text { 4. Mengajarkan klien cara berkenalan } \\
\text { Menganjurkan klien memasukan kegiatan latihan } \\
\text { berkenalan kedalam } \\
\text { Sp } 2 \text { Isolasi Sosial } \\
\text { 1. Memberikan kesempatan pada klien } \\
\text { memperaktikan cara berkenalan. } \\
\text { 2. Mengajarkan klien berkenalan dengan orang } \\
\text { pertama (seorang perawat) }\end{array}$ & $\begin{array}{l}\text { hobi memasak kue, asal saya dari medan, } \\
\text { nama suster siapa, hobi suster apa, asal } \\
\text { suster dari mana. } \\
\text { belum mampu menyebutkan keuntungan } \\
\text { dan kerugian mempunyai teman }\end{array}$ \\
\hline $\begin{array}{l}\text { Jumat, } 12 \text { Maret } 2020 \\
\text { 10:00 Wib }\end{array}$ & $\begin{array}{l}\text { SP-3 Isolasi Sosial } \\
\text { 1. Memberikan kesempatan kepada klien } \\
\text { memperaktikan cara berkenalan dengan orang } \\
\text { pertama } \\
\text { 2. melatih pasien berinteraksi secara bertahap } \\
\text { (pasien dengan } 4-5 \text { orang), latihan bercakap- } \\
\text { cakap saat melakukan kegiatan harian baru.S }\end{array}$ & $\begin{array}{l}\text { S : senang } \\
\mathrm{O}: \text { - Pasien mampu menjawab sapaan, mau } \\
\text { berjabat tangan mampu menyebutkan nama } \\
\text { lengkap tidak bicara lambat (suara pelan } \\
\text { hampir tidak terdengar) mau duduk }\end{array}$ \\
\hline
\end{tabular}




\begin{tabular}{|c|c|c|}
\hline & $\begin{array}{l}\text { SP-4 Isolasi Sosial } \\
\text { 1. Memberikan kesempatan pada klien } \\
\text { memperaktikan cara meminta sesuatu } \\
\text { 2. kemampuan berinteraksi, melatih cara } \\
\text { berbicara saat melakukan kegiatan social } \\
\text { seperti beberlanja dan minta tolong }\end{array}$ & $\begin{array}{l}\text { berdampingan dengan perawat. } \\
\text { - } \text { mampu menyebutkan keuntungan dan } \\
\text { kerugian mempunyai teman } \\
\text { A : isolasi sosial (+) } \\
\text { P : lanjutkan SP 3. } \\
\text { - } \text { latihan memperkenalkan diri nama, umur, } \\
\text { tempat tinggal, hobi } \\
\text { - latihan berkenalan dengan orang lain } \\
\text { - } \text { Selamat pagi, saya latihan berkenalan, } \\
\text { selamat pagi perkenalkn nama saya W } \\
\text { hobi memasak kue, asal saya dari medan, } \\
\text { nama suster siapa, hobi suster apa, asal } \\
\text { suster dari mana. Suster lagi ngapain, } \\
\text { nanti suster datang lagi? } \\
\text { melatih cara berbicara saat melakukan } \\
\text { kegiatan social. } \\
\text { Suster saya minta tolong belikan saya } \\
\text { lontong yang banyak kuahnya }\end{array}$ \\
\hline Selasa, 16 Maret 2021 & SP1 Harga Diri Rendah Kronis & S: senang \\
\hline
\end{tabular}




\begin{tabular}{|c|c|c|}
\hline & $\begin{array}{l}\text { 1. Mengidentifikasi aspek positif yang ada } \\
\text { pada klien } \\
\text { 2. Mengidentifikasi kegitan klien yang } \\
\text { dapat dilakukan } \\
\text { SP2 Harga Diri Rendah Kronis } \\
\text { 3. Menetapkan kegiatan yang dipilih } \\
\text { 4. Melatih klien melakukan kegiatan yang } \\
\text { telah dipilih }\end{array}$ & $\begin{array}{l}\text { O : - klien menyebutkan aspek positif yang ia miliki } \\
\text { - } \text { Klien mengatakan dapat mencuci mengambar, } \\
\text { menyanyi dan melipat kain } \\
\text { - } \text { Klien tampak nampak dapat mengambar } \\
\text { A : klien dapat memperaktekkan menggambar yaitu } \\
\text { mengambar bunga, ikat bebek, dan kupu -kupu. } \\
\text { P : motivasi klien untuk menggambar dalam jadwal } \\
\text { kegiatan harian }\end{array}$ \\
\hline $\begin{array}{l}\text { Kamis } 18 \text { Maret } 2021 \\
10: 30 \mathrm{Wib}\end{array}$ & $\begin{array}{l}\text { SP3 Harga Diri Rendah Kronis } \\
\text { 1. Menetapkan kegiatan yang dipilih ke } \\
\text { dua } \\
\text { 2. Melatih klien melakukan kegiatan yang } \\
\text { telah dipilih kedua } \\
\text { SP4 Harga Diri Rendah Kronis } \\
\text { 1. Menetapkan kegiatan yang dipilih } \\
\text { 2. Melatih klien melakukan kegiatan yang } \\
\text { telah dipilih }\end{array}$ & 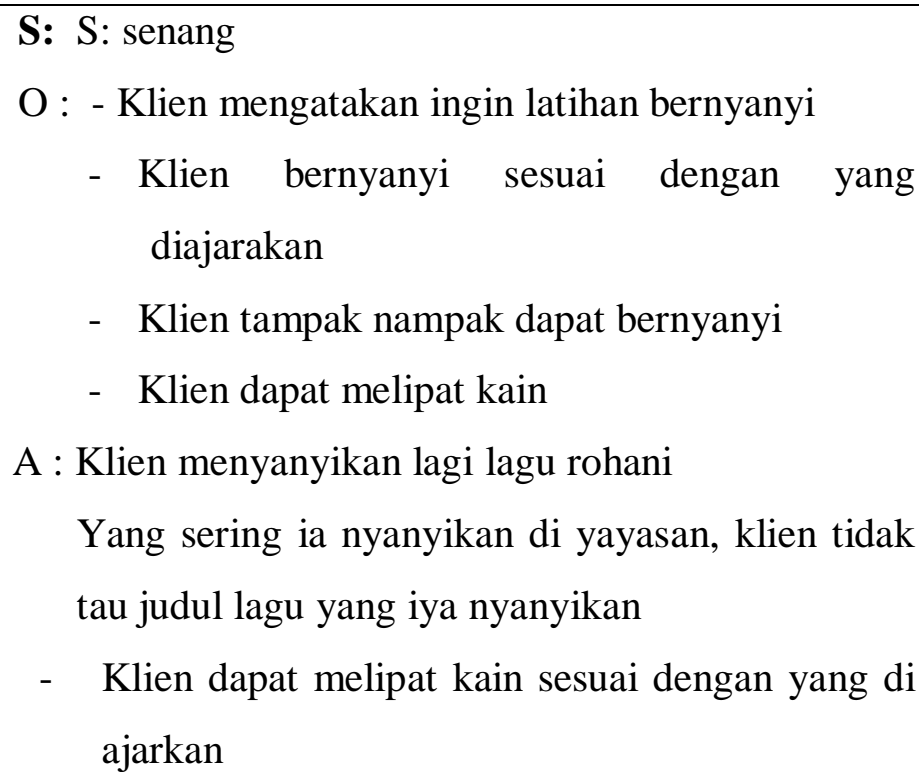 \\
\hline
\end{tabular}




\begin{tabular}{|l|l|c|}
\hline & & $\begin{array}{c}\text { P : motivasi klien untuk menyanyi dan melipat kain } \\
\text { dalam jadwal kegiatan harian }\end{array}$ \\
& & Latih klien untuk melakukan kegiatan lainnya \\
\hline
\end{tabular}




\section{BAB 4 \\ PEMBAHASAN}

Setelah penulis melaksanakan asuhan keperawat kepada Ny.W dengan gangguan Isolasi Sosial di Yayasan Pemenang Jiwa maka penulis pada BAB ini akan membahasan kesenjangan antara teoritis dengan tinjauan kasus. Pembahasan dimulai melalui tahapan proses keperawatan yaitu pengkajian, diagnosa keparawatan, perencanaan, pelaksanaan dan evaluasi.

\subsection{Pengkajian}

Pada pembahasan ini diuraikan tentang hasil pelaksanaan tindakan keperawatan dengan pemberian terapi generalis pada klien Isolasi Sosial. Pembahasan menyangkut analisis hasil penerapan terapi generalis terhadap masalah keperawatan Isolasi Sosial. Tindakan keperawatan didasarkan pada pengkajian dan diagnosis keperawatan yang terdiri dari tindakan generalis yang dijabarkan sebagai berikut.

Tahap pengkajian pada klien Isolasi Sosial dilakukan interaksi perawat-klien melalui komunikasi terapeutik untuk mengumpulkan data dan informasi tentang status kesehatan klien. Pada tahap ini terjadi proses interaksi manusia, komunikasi, transaksi dengan peran yang ada pada perawat sebagaimana konsep Peplau tentang manusia yang bisa dipengaruhi dengan adanya proses interpersonal.

Selama pengkajian dilakukan pengumpulan data dari beberapa sumber, yaitu dari pasien dan tenaga kesehatan di ruangan. Penulis mendapat sedikit kesulitan dalam menyimpulkan data karena keluarga pasien jarang mengunjungi pasien di yayasan. Maka penulis melakukan pendekatan kepada pasien melalui komunikasi terapeutik yang lebih terbuka membantu pasien untuk memecahkan perasaannya dan juga melakukan observasi kepada pasien.

Adapun upaya tersebut yaitu: 
1. Melakukan pendekatan dan membina hubungan saling percaya diri pada klien agar klien lebih terbuka dan lebih percaya dengan menggunakan perasaan.

2. Mengadakan pengkajian klien dengan wawancara

3. Mengadakan pengkajian dengan cara berbicara dengan pasien dan petugas yayasan.

Dalam pengkajian ini, penulis tidak menemukan kesenjangan karena ditemukan hal sama seperti pada tinjauan teoritis. Pada kasus Ny.W, Banyak berdiam diri di kamar, klien menyendiri dan tidak mau berinteraksi dengan orang yang terdekat, klien tampak sedih, ekspresi datar dan dangkal, kontak mata kurang, Apatis (acuh terhadap lingkungan), Ekpresi wajah kurang berseri

Tindakan keperawatan terapi generalis yang dilakukan pada Ny.w adalah strategi pertemuan pertama sampai pertemuan ketiga. Strategi pertemuan pertama meliputi Menggajarkan Keuntungan Dan Kerugian Mempunyai Teman dan melatih pasien untuk berkenalan dengan 2 orang atau lebih. Strategi pertemuan kedua yang dilakukan pada Ny.S meliputi melatih cara mengendalikan dengan bercakap-cakap kepada orang lain sambil beraktifitas berbelanja tau meminta tolong, , melakukan kegiatan positif seperti mengambar, melipat kain. menyusun jadwal kegiatan bersama-sama dengan klien

\subsection{Diagnosa Keperawatan}

Pada Teori Isolasi Sosial (NANDA, 2015-2017), diagnosa keperawatan yang muncul sebanyak 2 diagnosa keperawatan yang meliputi:

1. Isolasi Sosial

2. Harga Diri Rendah Kronis

Sedangkan pada kasus Ny.S ditemukan dua diagnosa keperawatan yang muncul yang meliputi:, Isolasi Sosial, Harga Diri Rendah. Dari hal tersebut di atas dapat dilihat terjadi kesenjangan antara teori dan kasus. Dimana semua diagnosa pada teori muncul pada kasus Ny.W 


\subsection{Implementasi}

Pada tahap implementasi, penulis mengatasi 2 masalah keperawatan yakni: diagnosa keperawatan isolasi sosial, dan harga diri rendah kronis . Pada diagnosa keperawatan isolasi sosial dilakukan strategi pertemuan yaitu mengajarkan keuntungan dan kelebihan mempunyai teman, Kemudian strategi pertemuan yang dilakukan yaitu berkenalan dengan dua orang atau lebih dan anjurkan berkenalan dengan sambil melakukan kegiatan harian, strategi pertemuan yang ke dua yaitu latihan dengan cara bercakap-cakap pada saat aktivitas, mengidentifikasi kemampuan aspek positif yang dimilki, melatih kegiatan yang telah di pilih 1sampai 3 dan melatih klien melakukan semua jadwal kegiatan. Untuk melakukan implementsi pada keluarga, pada tahap-tahap diagnosa tidak dapat dilaksanakan karena penulis tidak pernah berjumpa dengan keluarga klien (keluarga tidak pernah berkunjung).

\subsection{Evaluasi}

Pada tinajauan teoritis evaluasi yang diharapkan adalah: Pasien mempercayai perawat sebagai terapis, pasien menyadari bahwa yang dialaminya tidak ada objeknya, dapat berinteraksi dengan orang lain , dapat melakukan interaksi dengan orang lain , latihan bercakap-cakap, sambil melakukan aktivitas serta melakukan kegiatan yang positif.

Pada tinjauan kasus evaluasi yang didapatkan adalah: Klien mampu mengungkapkan keuntungan dan kelebihan mempunyai teman, Klien mampu melakukan latihan berkenalan dengan orang lain, Klien mampu melaksanakan jadwal yang telah dibuat bersama, Selain itu, dapat dilihat dari setiap evalusi yang dilakukan pada asuhan keperawatan, dimana terjadi penurunan gejala yang dialami oleh Ny.W dari hari kehari selama proses interaksi seperti suara 


\section{BAB 5 \\ PENUTUP}

\subsection{Kesimpulan}

Berdasarkan uraian pada pembahasan di atas, maka penulis dapat disimpulkan bahwa:

1. Pengkajian dilakukan secara langsung pada klien dan juga dengan menjadikan status klien sebagai sumber informasi yang dapat mendukung data-data pengkajian. Selama proses pengkajian, perawat mengunakan komunikasi terapeutik serta membina hubungan saling percaya antara perawat-klien. Pada kasus Ny.W, diperoleh bahwa klien mengalami gejala-gejala Isolasi Sosial seperti tidak mau berinteraksi dengan orang lain, sering menyendiri, tidak mau diajak berbicara, kurrang kontak mata saat berbicara. Faktor predisposisi pada Ny.W yaitu pernah mengalami kejadian ditinggal oleh anak dan suaminya.

2. Diagnosa keperawatan yang muncul pada kasus Ny.W sebanyak: isolasi sosial dan harga diri rendah kronis .

3. Perencanaan dan implementasi keperawatan disesuaikan dengan strategi pertemuan pada pasien Isolasi sosial.

4. Evaluasi dperoleh bahwa terjadi peningkatan kemampuan klien dalam berinteraksi dengan orang lain.

\subsection{Saran}

1. Bagi Perawat

Diharapkan dapat meenrapkan komunikasi terapeutik dalam pelaksanaan strategi pertemuan 1-4 pada klien dengan isolasi sosial sehingga dapat mempercepat proses pemulihan klien.

\section{Bagi Institusi Pendidikan}

Dapat meningkatkan bimbingan klinik kepada mahasiswa profesi ners sehingga mahasiswa semakin ampu dalam elakukan asuhan keperawatan pada pasienpasien yang mengalami isolasi sosial. 


\section{Bagi Yayasan}

Laporan ini diharapkan dapat menjadai acuan dan referensi dalam memberikan asuhan keperawatan pada klien dengan Isolasi Sosial. 


\section{DAFTAR PUSTAKA}

1. Azizah, F. N., Hamid, A. Y. S., \& Wardani, I. Y. (2017). Respon Sosial dan Kemampuan Sosialisasi Pasien Isolasi Sosial melalui Manajemen Kasus Spesialis Keperawatan Jiwa. Media Ilmu Kesehatan, 6(2), 91-100. https://doi.org/10.30989/mik.v6i2.221

2. Damanik, R. K., Pardede, J. A., \& Manalu, L. W. (2020). Terapi Kognitif Terhadap Kemampuan Interaksi Pasien Skizofrenia Dengan Isolasi Sosial. Jurnal Ilmu Keperawatan dan Kebidanan,11(2), 226-235. http://dx.doi.org/10.26751/jikk.v11i2.822

3. Dermawan, D., \& Rusdi. (2013). Keperawatan jiwa konsep dan kerangka kerja asuhan keperawatan jiwa. Gosyen publishing : Yogyakarta.

4. Fadly, M., \& Hargiana, G. (2018). Studi Kasus: Asuhan Keperawatan Pada Klien Isolasi Sosial Pasca Pasung. Faletehan Health Journal, 5(2), 90-98. https://doi.org/10.33746/fhj.v5i2.14

5. Kirana, S. A. C. (2018). Gambaran Kemampuan Interaksi Sosial Pasien Isolasi Sosial Setelah Pemberian Social Skills Therapy Di Rumah Sakit Jiwa. Journal of Health Sciences, 11(1). https://doi.org/10.33086/jhs.v11i1.122

6. Ni'mah, Anik Lailatun (2019) Hubungan Status Mental Dengan Interaksi Sosial Pada Orang Dengan Isolasi Sosial di Griya Cinta Kasih Jogoroto Jombang. Undergraduate thesis, STIKes Insan Cendekia Medika Jombang. http://repo.stikesicme-jbg.ac.id/id/eprint/2253

7. Pardede, J. A., Simanjuntak, G. V., \& Laia, R. (2020). The Symptoms of Risk of Violence Behavior Decline after Given Prgressive Muscle Relaxation Therapy on Schizophrenia Patients. Jurnal Ilmu Keperawatan Jiwa,3(2), 91-100. http://dx.doi.org/10.32584/jikj.v3i2.534

8. Pardede, J. A. (2018). Pelaksanaan Tugas Keluarga Dengan Frekuensi Kekambuhan Pasien Skizofrenia Dengan Masalah Isolasi Sosial. Jurnal Keperawatan Jiwa, 6(2).

9. Pardede, J. A., Hamid, A. Y. S., \& Putri, Y. S. E. (2020). Application of Social Skill Training using Hildegard Peplau Theory Approach to Reducing Symptoms and the Capability of Social Isolation Patients. Jurnal Keperawatan, 12(3), 327340. https://doi.org/10.32583/keperawatan.v12i3.782

10. Pardede, J. A. (2017). The Implementation of Family Tasks with The Frequency of Recurrence of Social Isolation Patients. Mental Health, 4(2). 
11. Pardede, J. A., \& Ramadia, A. (2021). The Ability to Interact With Schizophrenic Patients through Socialization Group Activity Therapy. International Journal

12. Riskesda (2013). Penyajian Pokok Pokok Hasil Riset Kesehatan Dasar 2013. http://kesga.kemkes.go.id/images/pedoman/Dat a\%20Riskesdas\%202013.pdf

13. Riskesdas (2018) Hasil Utama Riskesdas 2018 Kementerian Kesehatan Badan Penelitian dan Pengembangan Kesehatan.

https://www.kemkes.go.id/resources/download/ info-terkini/hasil-riskesdas2018.pdf

14. Riyadi S \& Purwanto T. (2013). Asuhan Keperawatan Jiwa. Yogyakarta: GRAHA ILMU

15. Stuart, G. W. (2016). Prinsip Dan Praktik Keperawatan Jiwa (II). Jakarta: Binarupa Aksara.

16. Sumarno, K. (2019). Asuhan Keperawatan Pada Tn. FPB Dengan Isolasi Sosial: Menarik Diri Di Ruang Rawat Inap Rumah Sakit Jiwa Naimata Kupang Provinsi Nusa Tenggara Timur (Doctoral dissertation, Poltekkes Kemenkes Kupang). http://repository.poltekeskupang.ac.id/eprint/22536

17. Try, O. (2017). Hubungan Antara Perilaku Perawatan Terhadap Penerapan Strategi Pelaksanaan Pada Pasien Isolasi Sosial Di Ruang Rawat Inap Rumah Sakit Ernaldi Bahar Provinsi Sumsel Tahun 2017 (Doctoral Dissertation, Stik Siti Khadijah Palembang). http://repository.stik-sitikhadijah.ac.id/eprint/24599

18. Wahyuni, Sri, Nurul. (2017). Asuhan Keperawatan Jiwa. Ponorogo: Unmuh Ponorogo Press.

19. WHO (2019). Schizophrenia. Retrieved from. https://www.who.int/newsroom/fact-sheets/\%20detail/schizophrenia 